\title{
Training of Sustainable Development Specialists Within the Environmental Education System
}

\author{
Galina Viphanova, Natalia Voronina, and Natalia Vedysheva* \\ Kutafin Moscow State Law University (MSAL), Moscow, Russia
}

\begin{abstract}
The achievement of sustainable development goals necessitates further theoretical reflection and revision of approaches to educational activities, considering the global challenges and threats of our time. In the context of sustainable development concept paradigm, the educational process is considered within the ecological model, which is demanded in training and retraining of specialists of different profiles, possessing knowledge, abilities, and skills, necessary for state policy implementation, management organization, making effective decisions in the sphere of society and nature interaction, eliminating contradictions and achieving the balance of economic, ecological and social interests. The authors, having analyzed the works of scientists, investigated the Voluntary Report of the Russian Federation on the implementation of the SDGs in Russia in 2019, and Rosstat data highlighted the need for environmental management. Current areas of educational programs in the field of sustainable development are proposed.
\end{abstract}

\section{Introduction}

In the context of the growing civilizational crisis of our time, due to the emergence of new challenges and threats associated with the pandemic of coronavirus infection, potential and real risks of the emergence of new zoonotic and other diseases, climatic changes, the persistence of trends in the depletion of the resource base, reduction of biological resources, degradation of natural ecological systems, the onset of other the negative consequences of the anthropogenic impact of economic and other activities on the environment and humans, there is an increase in the attention of the world community and individual states to the search and optimization of mechanisms for implementing the concept of sustainable development as the only way (model) that can ensure the survival of humankind and the preservation of the biosphere.

One of the key tools to achieve the targets of this concept is education in sustainable development, which is a prerequisite and a means of achieving the goals, objectives, indicators of this model developed by the international community in the 1970 s $[1,2,3,4$, 5]. With the formation and development of a new civilization model in the late XX - early XXI centuries, there is an evolutionary construction and improvement of strategies for sustainable development at the international, national level, including Russia.

\footnotetext{
* Corresponding author: veda120006@yandex.ru
} 
Implementation of educational programs for sustainable development is a necessary condition and basis for formation in the process of educational activities of knowledge, abilities, and skills for strategic planning, organization and management of social structure based on the laws of nature development, harmonization of relations between the society and environment, as well as environmentally-oriented and socially responsible behavior of business and entrepreneurs in carrying out their economic activities

Accordingly, the basis of the modern model of education for sustainable development is environmental education, the subject area of which is the study of the sphere of interaction between society and nature, including the contradictions that arise between them, ways to overcome them, ways to solve global, interregional, regional and local environmental problems, means of exercising environmental rights of citizens and public organizations (associations), ensuring the environmental interests of various social strata of the population (women, youth, indigenous peoples, etc.), organizational and financial and economic mechanisms of environmental management, other instruments (including legal) for regulating public relations, including nature management, environmental protection, environmental and other types of safety.

"Ecological component" of sustainable development education should include the model of environmental education (general and professional) and consider aspects of the influence of all education on solving environmental problems of civilization [6 P. 37]. And the inclusion of the environmental component of education for sustainable development is necessary both in the form of ecologization of education and professional environmental education [6 P. 47]. These tasks should be highlighted among Russia's state education policy priorities within the system of lifelong education, training, and retraining of professional staff.

The modern education paradigm - "education for sustainable development" - requires training of effective specialists based on educational standards and programs meeting modern challenges and threats, developed following international agreements and national legislation in this field, taking into account positive foreign experience.

\section{Research Methodology}

When investigating the issues related to training specialists in sustainable development, the method of theoretical analysis of scientific sources related to the development of the concept and objectives of sustainable development, education for sustainable development, environmental model of implementation of this direction of educational activity was applied. General scientific methods (synthesis, comparison, generalization) allowed obtaining research results on developing education for sustainable development and improving training directions in this sphere, considering ecological components.

\section{Findings}

The current state and prospects of Education for Sustainable Development are linked to achieving the global goals adopted at the 70th UN General Assembly at the Sustainable Development Summit in September 2015. The 2030 Agenda for Sustainable Development [7] included the Global Sustainable Development Goals (SDGs), which are a continuation of the targets of all previous UN documents in this area, as well as the Millennium Development Goals identified as priority international development goals in the Declaration millennium, adopted by the UN member states in 2000 [8].

Among the SDGs, Goal 4 was singled out as "Ensure inclusive and equitable quality education and promote lifelong learning opportunities for all", which the UN and UNESCO 
see as a new vision for world education. This recognizes the important role of education as a key driver of development and in achieving the other proposed SDGs.

The SDGs in the proposed 2030 Agenda for Sustainable Development consist of 17 Sustainable Development Goals and 169 related targets, which are integrated, indivisible, and represent a set of global priorities and parameters for sustainable development [9], including environmental ones. Environmental SDGs include: ensure availability and sustainable management of water and sanitation for all (SDG 6); take urgent action to combat climate change and its impacts (SDG 13); conserve and sustainably use the oceans, seas, and marine resources for sustainable development (SDG 14); protect, restore and promote sustainable use of terrestrial ecosystems, sustainably manage forests, combat desertification, and halt and reverse land degradation and halt biodiversity loss (SDG 15). However, the environmental component is present and should be ensured through the objectives of achieving other sustainable development targets aimed at ending hunger, achieving food security and improving nutrition, and promote sustainable agriculture (SDG 2); ensure access to affordable, reliable, sustainable, and modern energy for all (SDG 7); ensure sustainable consumption and production patterns (SDG 12), etc.

The need for ecologization of all sustainable development goals and the reflection of the environmental component in the objectives of their achievement is due to the increasing anthropogenic load of economic and other activities on the environment and human health. This is evident from the statistics and findings of the UN Environment Program (2019). "Global Environment Outlook (GEO6): a healthy planet - healthy people" (2019, Nairobi) [10]. Along with the assessment of current scientific information and data, the report analyzes past and current environmental policies and formulates future options for achieving the 2050 Sustainable Development Goal.

Climate change has been identified as a priority issue affecting both human systems, including human health, and natural systems - air, biodiversity, freshwater, oceans, and land - changing the complex interactions between these systems. Air pollution is a major environmental factor in the global burden of disease, resulting in 6 to 7 million premature deaths. Genetic diversity is in decline, threatening food security and the sustainability of ecosystems, including the farming system and food security. Global energy consumption is expected to increase significantly between 2014 and 2040 (by 63\%) in countries using fossil fuels[10].

These and other manifestations of globalization continued extensive use of natural resources, resulting in depletion and reduction in natural resources, increasing negative impact of fuel and energy complex and other sectors of the economy on the environment, which results in disturbance and degradation of ecosystems and natural environment components cause the need to review the interaction between society and nature, including management of socio-economic development, organization of the production process, training in environmental and social aspects of environmental protection.

Education for sustainable development is therefore critical to achieving sustainable development goals, creating a more sustainable society, and addressing inevitable environmental change. While significant progress has been made worldwide over the past decades in embedding education for sustainable development in all education sectors, there is a need for scaling up, mainstreaming, and reviewing approaches to education standards and curricula. Education for sustainable development is generally seen and pursued in the context of systemic economic, environmental, and social interlinkages. These priorities aim to form a "three-dimensional" systemic (economic-environmental-social) approach driven by the need to make managerial, economic, and other decisions to overcome contradictions and achieve a balance of economic, environmental, and social interests. This does not mean that other areas of societal development remain outside this approach. At the same time, education 
for sustainable development should considerably include environmental components both in the form of ecologization of education and professional environmental education.

The needs for greening educational activities are evident in the training of specialists in various segments of the economy, such as the extractive industries [11], mineral processing [12]. energy [13], low-carbon economy[14].

Today, Russian universities are taking some steps to develop educational programs aimed at developing green technology competencies (for example, master's programs "Energyefficient low-carbon (green) economy" and "Green economy and finance"). Still, there are no references or indications of green competencies in the Federal State Educational Standards of Secondary Vocational Education and Higher Education.

Ecologization of the educational process of training specialists, along with the energy sector, should cover other sectors of the economy - agriculture, subsoil use, forestry and timber complex, mining, processing, resource-intensive industries, transport sector, as well as metallurgical, chemical, and other enterprises, which make the largest contribution to the total mass of greenhouse gas emissions.

Accordingly, when developing educational training as well as retraining programs within the framework of environmental education model for sustainable development, apart from general issues (concept, goals, objectives, indicators (indicators) and tools), it is necessary to highlight measures of environmental and legal support of the green economy, implementation of green projects, low-carbon economy, bio-economy, renewable and alternative energy, other sectors of the economy and social sphere.

It is necessary to emphasize the necessity of development and implementation of educational programs on environmental and legal support of sustainable development in the direction of training (specialty) "Jurisprudence" to form knowledge and skills on the preparation of drafts of regulatory legal acts, managerial decisions, and law enforcement activity, based on principles and provisions of sustainable development concept, oriented to achieving balance in the sphere of interaction between society and nature. A similar need is noted in environmental management [15], the introduction of environmental innovations [16], which is due to the need to organize environmentally friendly and environmentally friendly economic and other activities.

Implementation of the environmental model of education for sustainable development is also relevant for managerial staff of the authorities, which carry out their activities in various areas of socio-economic and environmental development of the society, including the implementation of national projects, including the sphere of environmental management, environmental protection, and environmental safety.

Thus, the ecological model of education for sustainable development is an integral and necessary condition for the optimization and harmonization of modern society in the context of global challenges and threats.

\section{Discussion}

Education for Sustainable Development is a relevant and controversial area of contemporary scientific research. One of the most frequently discussed issues lies in the understanding of the concept of sustainable development, which, according to some experts, is not enough to consider only the relationship between economy, environment, and social sphere (SD triad) because these priorities are much more, and they change over time. Therefore, focusing on forming a systemic but only "three-dimensional" approach can be perceived as a kind of limitation to the further development of the concept of sustainable development. It is proposed to supplement the triad with an educational direction, separated from the social sphere, which, however, acts as an information interaction between society, personality, and nature [9]. 
However, education is one of the tools to implement the concept and achieve sustainable development goals, along with other mechanisms - public policy, strategic planning, digitalization, innovation, investment, state support measures, etc.

When assessing the content of the concept of sustainable development, one should distinguish this concept from the term "sustainability" (stability, equilibrium, constancy) used in different spheres and directions: "sustainability" of financial, banking, transport system, investments, fiscal sphere, etc. Identifying the "triad" elements that make up the concept of sustainable development is due to the contradictions between the economic, environmental, and social needs and interests of society. Their conflicting nature lies in the nature of the economic activity, most of which is associated with the use of natural resources, in the process of which depletion, reduction, exhaustion of natural resources occurs, on the one hand, and on the other - their potential and real negative impact on the environment and public health, which in turn leads to violations of environmental human rights. Therefore, the concept of sustainable development is aimed at finding and optimizing forms of interaction between society and nature, providing the maximum mitigation of such contradictions, and achieving a balance between economic, environmental, and social interests through various measures and tools, including education. Consequently, the role and importance of the ecological model in the educational process for sustainable development increase, the application of which is aimed at training and retraining specialists able to organize and implement activities in various spheres, make economic, managerial, and other decisions that ensure the achievement of sustainable development goals, most of which are ecological or have ecological content.

\section{Conclusions}

Implementation of the concept of sustainable development as a unique alternative for survival of modern society in conditions of increase of global challenges and threats, the occurrence of new diseases, including the pandemic of coronavirus infection, civilization crisis (natural resources, energy, ecological, climatic, food and others) requires reorganization both everyday and professional consciousness, based on the understanding of the interrelation of society and nature, the necessity of their accounting at the realization of national policy on achievement of sustainable development and sustainable development.

The ecological model of education for sustainable development is aimed at training personnel for organizing and carrying out economic and other activities, managing various areas, making environmentally sound and environmentally friendly decisions in accordance with educational programs, which should include the following areas: concept, goals, objectives, indicators (indicators) sustainable development; international agreements, national and foreign legislation in the field of sustainable development; sustainable development goals and their achievement in the context of global challenges and threats; features and measures to achieve the SDGs in the economy and energy (green projects, green investments, low-carbon energy and the economy), agriculture, and other sectors; formation and improvement of the system of sustainable spatial development; digitalization in order to achieve the goals and objectives of sustainable development; environmental and legal support for the implementation of the concept of sustainable development (environmental requirements for economic and other activities, rational use of natural resources, environmental protection, methods and tools for achieving international and national security (environmental, climatic, food, genetic, biological). These directions are not exhaustive and can be adjusted depending on objective reasons related to the emergence of new challenges and threats, national and territorial specifics, and other destabilizing social development factors. 


\section{References}

1. G.V. Vypkhanova, Bulletin of the University named after O.E. Kutafina 1(17), 64 (2016).

2. I.V. Ilyin, V.A. Los, A.D. Ursul, Bulletin of Moscow University. Series 27. Globalistics and Geopolitics 1-2, 49 (2015)

3. I.V. Ilyin, A.D. Ursul, T.A. Ursul, Bulletin of Moscow University. Series XXVII: Globalistics and Geopolitics 1-2,61 (2016)

4. A.D. Ursul, National Security / nota bene 5, 683 (2015)

5. A.D. Ursul, Ecological Yearbook 8, 50 (2015)

6. V.A. Grachev, I.V. Ilyin, A.D. Ursul, T.A. Ursul, A.N. Andreev, Education for Sustainable Development in Russia: Problems and Prospects (Expert and Analytical Report), 207 p. (M.: Moscow edition of the Uchitel publishing house; Moscow University Publishing House, 2017)

7. Transforming our world: the 2030 Agenda for Sustainable Development. https://sustainabledevelopment.un.org/post2015.

8. UN Millennium Declaration, 2000. www.un.org.

9. I.V. Ilyin, A.D. Ursul, T.A. Ursul, Bulletin of Moscow University. Series XXVII: Globalistics and Geopolitics 3-4, 60 (2015)

10. United Nations Environment Program. Global Environment Outlook (GEO-6): Healthy Planet, Healthy People. Summary for policymakers (Nairobi) (2019)

11. S. Zhironkin, S. Demchenko, G. Kayachev, M. Ryzhkova, O. Zhironkina, Neo-Industrial Base for Sustainable Development of Raw-Materials Cluster. E3S Web of Conferences 41, 1 (2018)

12. E. Zhernov, E. Nehoda, Ecological and economic component of personnel training for mineral processing enterprises. E3S Web of Conferences 41, 04009 (2018)

13. V. Kolibaba, I. Kukukina, A. Morozova, Issues of sustainable energy development in the context of de-globalization of the world economy. E3S Web of Conferences 208, 02010 (2020)

14. A. Kolpakov, Low-carbon development strategy of Russia considering the impact on the economy. In the collection: E3S Web of Conferences 209, 05005 (2020)

15. M. Mukhlynina, N.O. Vedysheva, Legal aspect of the implementation of the UN Sustainable development goals in the field of environmental management in Russia. In the collection: E3S Web of Conferences. Actual Problems of Ecology and Environmental Management: Cooperation for Sustainable Development and Environmental Safety, APEEM 2020, 05003; M. Mukhlynina, N. Mishina, N. Vedysheva, I. Shikula, Legal regulation of the circular economy and ecology: current issues. SHS Web of Conferences 89, 04003 (2020) Conf-Corp 2020

16. G.V. Vypkhanova, Legislation 3, 22 (2020) 